\title{
El arte como fortín. Lo que la guerra no podrá erosionar
}

\author{
Miguel Gutiérrez-Peláez* \\ Universidad del Rosario, Bogotá, Colombia
}

Cada cierto tiempo aparecen sujetos y grupos humanos que logran hacer un alto en el camino, frenar el automatismo de asesinatos, dolor y crueldad, y producir un acto de creación, inédito, que parecía imposible en esas condiciones adversas. La única opción no es descender en masa por la misma espiral, o elegir entre las opciones maniqueas y binarias que difunden los medios y replican las redes y que se reeditan en los debates sociales. Incluso, podemos aprender de estos actos que, más que apresurar una posición superflua y banal, apuntan a una detención, a una suspensión del incansable vértigo del tiempo.

¿Cómo transmitir lo trascendente del acto de empuñar un pincel o una aguja en vez de un machete o un fusil? El arte es la huella misma de lo vivo, la evidencia de que la guerra no arrasa con toda la humanidad (Gutiérrez-Peláez, 2017). Subyacen, aún, a pesar de todo, pequeños resquicios, fortines de resistencia, desde los cuales puede recomponerse la dignidad humana y alzarse voces que sean actos de construcción de otro mundo posible. Es el amor por las generaciones por venir, que no tienen por qué padecer, también, los horrores que lesionaron a las generaciones actuales.

Encontramos creaciones anónimas de valentía y resistencia en varios rincones del país, algunas de las cuales no harán parte nunca de la memoria histórica de nuestro pueblo. Otras, afortunadamente, salen del plano doméstico de la comunidad y logran cierta difusión, lo que nos da la oportunidad de aprender. Es el caso de las mujeres de
Mampuján, quienes encontraron en los telares un modo de escribir y sanar la violencia que vivieron en los Montes de María, Córdoba (Colombia), proveniente de las manos de grupos paramilitares que asesinaron a miembros de su comunidad y desplazaron a la totalidad de un pueblo (Grupo de Memoria Histórica, 2013, p. 276).

Las tejedoras de Mampuján, como se dieron a conocer, ponen en un acto su modo particular de hacer frente a los horrores que transformaron para siempre sus vidas, esos cruentos sucesos contra doce campesinos bajo las ramas de un tamarindo. Aún hoy interrogan a ese árbol, testigo mudo de las palabras finales de sus familiares y amigos. Las mujeres comenzaron a anudar con hilos lo roto de su historia. Alzaron la voz mientras lo hacían, hablando, y fueron grabando en la tela sus relatos. Más que lo que puede leerse y verse en el telar, conmueve el acto mismo de tejer, de hacerlo en comunidad -inicialmente entre mujeres y luego con algunos hombres que se suman-e ir hilando juntos los acontecimientos. Cuánto podemos aprender de esa valentía que, frente a tanto horror y tanta barbarie, han mantenido en alto la voz, no la han enterrado en las fosas en las que yacen sus familiares.

Rendimos tributo a quienes han optado por el trazo, el nudo, el color o la maza, en vez de la destrucción del otro o la propia. Esas apuestas son el tejido singular en el que se asienta la estructura ética de un pueblo y sobre el que se sostiene una convivencia posible.

* Director de la revista Avances en Psicología Latinoamericana. Correo electrónico: apl@urosario.edu.co 


\section{Referencias}

Grupo de Memoria Histórica (2013). Informe ;Basta ya! Colombia: Memorias de guerra y dignidad. Colombia: Imprenta Nacional.

Gutiérrez-Peláez, M. (2017). Contributions of Psychoanalysis for Psychosocial Interventions in Armed Conflict Scenarios. Peace and Conflict: Journal of Peace Psychology. Advance online publication. http://dx.doi.org/10.1037/ pac0000270 